\title{
LINGKUP KERJA PERAWAT DALAM PENINGKATAN BUDAYA KESELAMATAN PASIEN DI RUMAH SAKIT
}

\author{
Fanisa Nur Siregar \\ fanisanursiregar09@gmail.com
}

\section{LATAR BELAKANG}

Lingkup kerja perawat sangat besar dalam menjalankan asuhan keperawatannya di rumah sakit. Perawat sebagai tenaga kesehatan haruslah melakukan peningkatan budaya keselamatan pasien di rumah sakit. Budaya keselamatan pasien adalah suatu pondasi ataupun penegak utama dalam pelaksanaan keselamatan pasien. Di rumah sakit, pasien sangat berisiko terhadap kecelakaan dan penyakit akibat perawatan yang di dapatkan. Keberhasilan dalam penerapan keselamatan pasien ini merupakan tanggung jawab seluruh komponen dalam rumah sakit termasuk perawat

Dalam upaya untuk meminimalisir terjadinya kesalahan akibat melaksanakan suatu tindakan atau tindakan yang seharusnya tidak diambil yang berkaitan dengan aspek keselamatan pasien dan kualitas rumah sakit, maka sangat diperlukan pentingnya membangun budaya keselamatan pasien. Budaya keselamatan pasien adalah nilai- nilai, sikap, persepsi kompetensi dan pola perilaku dari individu yang menentukan komitmen dan gaya kemampuan manajemen rumah sakit dalam meminimalkanpajanan yang membahayakan atau mencelakakan karyawan, manajemen pasien, atau anggota masyarakat lainnya.

Budaya keselamatan lainnya yaitu adanya alat ukur yang meyakinkan tentang keselamatan pasien, identifikasi proaktif terhadap ancaman laten keselamatan pasien, pembelajaran organisasi, komitmen pemimpin dan para staf serta pendekatan tidak menyalahkan terhadap pelaporan kejadian. Budaya keselamatan pasien negatif meliputi tingkat karir yang curam antar staf medis dengan staf lain, hubungan tim kerja yang renggang, dan keengganan mengakui kesalahan. Selain itu, perawat memiliki peran yang paling dominan dalam mencegah terjadinya kesalahan dalam pengobatan, termasuk pelaporan insiden, mendidik diri sendiri dan orang lain. Sejalan dengan definisi keperawatan ANA 2003 yang menyatakan bahwa keperawatan adalah perlindungan, promosi, dan optimalisasi kesehatan dan kemampuan, 
pencegahan penyakit dan cedera, pengentasan penderitaan melalui diagnosis dan pengobatan respon manusia, dan advokasi dalam perawatan individu, keluarga, masyarakat, dan populasi.

\section{METODE}

Metode dalam pembuatan jurnal ini dilakukan dengan cara mengumpulkan data dari buku, jurnal, dan thesis dan e-book, kemudian melakukan analisis secara mendalam terkait topik yang dibahas, serta bersifat subjektif yaitu proses penulisan yang lebih fokus pada landasan teori. Dan melakukan analisis buku dan e-jurnal yang relevan dan berfokus pada Lingkup Kerja Perawat Dalam Peningkatan Budaya Keselamatan Pasien Di Rumah Sakit. Dengan menggunakan sumber dengan terbitan paling tua tahun 2012. Adapun referensi akan dicantumkan dalam penulisan ini dengan jelas terdapat pada daftar pustaka pada bagian akhir penulisan.

\section{HASIL}

Keselamatan (safety) telah menjadi isu global termasuk juga untuk rumah sakit. Oleh karena itu, keselamatan pasien merupakan prioritas utama untuk dilaksanakan dan hal tersebut terkait dengan terjadinya Insiden Keselamatan Pasien (IKP) di rumah sakit. Keselamatan pasien adalah keadaan pasien bebas dari cedera yang tidak seharusnya terjadi atau bebas dari cedera yang potensial akan terjadi (penyakit, cedera fisik/sosial psikologis, cacat, kematian) terkait dengan pelayanan kesehatan (Depkes, 2008).

Keselamatan pasien merupakan hak bagi setiap pasien dan sudah sepatutnya menjadi kewajiban rumah sakit untuk memenuhi hak pasien tersebut (KARS, 2006). Pelaksanaan keselamatan pasien di Indonesia masih belum optimal, terbukti dari banyaknya kasus mal praktik yang dilaporkan oleh media massa. Keselamatan pasien dilaksanakan demi tercapainya 6 tujuan antara lain: ketepatan identifikasi pasien; peningkatan komunikasi yang efektif; peningkatan keamanan obat yang perlu diwaspadai; keamanan tindakan bedah; pencegahan risiko infeksi; dan pencegahan risiko pasien jatuh (Depkes, 2008). Budaya KP sebagai fondasi dalam usaha penerapan KP yang merupakan prioritas utama dalam pemberian layanan kesehatan (Disch, Dreher, Davidson, Sinioris, \& Wainio, 2011; NPSA, 2004). Fondasi KP yang baik akan meningkatkan mutu pelayanan kesehatan khususnya asuhan keperawatan. 
Upaya yang dapat dilakukan dalam peningkatan mutu pelayanan kesehatan adalah dengan budaya keselamatan pasien merupakan sebuah aspek yang menentukan kualitas pelayanan sebuah institusi kesehatan. Keberhasilan institusi ini tidak saja tercermin melalui indikator capaian kinerja finansial dan tingkat kepuasan pelanggan, tetapi juga melalui seberapa institusi tersebut mengedepankan keselamatan pasien sebagai sebuah budaya. Oleh karena itu, kesadaran tentang budaya keselamatan pasien masih perlu ditingkatkan. Salah satunya dengan memberikan pelatihan-pelatihan dan mengupdate pengetahuan pada perawat tentang pentingnya keselamatan pasien.

\section{PEMBAHASAN}

Keselamatan pasien rumah sakit adalah suatu sistem dimana rumah sakit membuat asuhan pasien lebih aman yang meliputi asesmen risiko, identifikasi dan pengelolaan hal yang berhubungan dengan risiko pasien, pelaporan dan analisis insiden, kemampuan belajar dari insiden dan tindak lanjutnya serta implementasi solusi untuk meminimalkan timbulnya risiko dan mencegah terjadinya cedera yang disebabkan oleh kesalahan akibat melaksanakan suatu tindakan atau tidak mengambil tindakan yang seharusnya diambil (Peraturan Menteri Kesehatan RI Nomor 1691, 2011)

Insiden keselamatan pasien tidak selamanya terjadi karena kesalahan manusia. Keselamatan pasien berhubungan dengan semua elemen di rumah sakit. Banyak faktor yang mempengaruhi terjadinya insiden keselamatan pasien, tidak hanya kesalahan individu tetapi dapat juga diakibatkan oleh kesalahan sistem (Baird \& Wang, 2010). Sistem yang kurang tertata merupakan kondisi yang sering kali menjadi faktor pencetus terjadinya kesalahan dalam keselamatan pasien. Peningkatan penerapan budaya keselamatan pasien yang hanya sebesar 7.4\% membuktikan bahwa membangun budaya keselamatan pasien memerlukan waktu yang lama dan tidak hanya melibatkan perawat tetapi semua elemen dalam organisasi (Armellino, et al., 2010).

Berdasarkan hasil penelitian terhadap indikator budaya keselamatan yang meliputi kerja sama, komunikasi, kepemimpinan, pelaporan dan respon tidak menghukum terhadap kesalahan didapatkan hasil dan pembahasan sebagai berikut : 


\section{1) Kerjasama}

Kerjasama merupakan indikator yang pertama dalam budaya keselamatan pasien. Berdasarkan hasil dari penelitian, dalam melaksanakan asuhan keperawatan kepada pasien perawat akan selalu membutuhkan bantuan dari perawat maupun tenaga kesehatan yang lainnya. Bentuk kerjasama tidak hanya berupa saling membantu pekerjaan ketika perawat dihadapkan pada tugas yang sangat banyak dan membutuhkan penyelesaian yang sesegera mungkin, namun juga bisa berupa pembagian tugas berdasarkan kelompok kecil atau tim dalam satu unit ruang rawat inap. Perawat adalah petugas kesehatan dengan waktu kerja tertinggi yang memberikan 24 jam pelayanan terus menerus, melakukan kolaborasi dengan tim kesehatan lain dan oleh karena hal tersebut dapat menyebabkan risiko terjadinya cidera1.

Keterlibatan banyak profesi selain tenaga perawat dalam melakukan asuhan keperawatan dapat menimbulkan atau berisiko terjadi cidera jika dilakukan tidak dengan komunikasi dan koordinasi yang tepat3, hal itu (cidera) dapat dihindari jika perawat selalu menjaga hubungan baik dengan sesama perawat dan petugas kesehatan lainnya, dan menjaga keharmonisan di lingkungan kerja atau suasana hati untuk mencapai pelayanan kesehatan.

\section{2) Komunikasi}

Komunikasi sangatlah penting dalam setiap melaksanakan tugas dalam hal ini adalah melaksanakan asuhan keperawatan pada pasien. Komunikasi yang baik dan benar perlu dilakukan untuk mengkoordinasikan asuhan keperawatan yang melibatkan banyak profesi selain profesi perawat. Komuniasi dalam praktek keperawatan merupakan elemen penting bagi perawat dalam melaksanakan asuhan keperawatan untuk mendapatkan hasil yang optimal3. Perawat memiliki peran yang paling dominan dalam mencegah terjadinya kesalahan dalam pengobatan, termasuk pelaporan insiden, mendidik diri sendiri dan perawat lain tentang penting komunikasi, memberikan rekomendasi untuk perubahan prosedur dan kebijakan serta keterlibatan dalam melakukan identifikasi permasalahan.

Kesalahan medis jarang disebabkan oleh faktor kesalahan manusia secara individual, tetapi lebih karena kesalahan pada sistem komunikasi yang menyebabkan terputusnya rantai dalam sistem tersebut. Hal ini menunjukkan pentingnya menjalin komunikasi dengan baik agar informasi yang disampaikan tidak terputus dan mengakibatkan kerugian pada pasien. Sistem dan 
interaksi manusia mengacu pada sistem dimana dua sistem berinteraksi atau berkomunikasi dalam ruang lingkup sistem tersebut6. Informasi tentang keselamatan pasien perlu diketau oleh semua perawat yang memberikan asuhan keperwatan hal tersebut berfungsi untuk mencegah perawat melakukan tindakan yang dapat menyebabkan cidera pada pasien. Komunikasi adalah kunci sukses berinteraksi dalam kehidupan berorganisasi. Ketika komuniksai efektif, arus informasi dalam organisasi yang dinamis akan berjalan lancar sehingga mempercepat proses tercapainya tujuan organisasi

\section{3) Kepemimpinan}

Pemimpin harus memiliki komitmen yang kuat terhadap keselamatan pasien, sehingga keselamatan pasien menjadi hal yang utama dalam memberikan pelayanan keperawatan. Pemimpin harus mampu menjadi agen perubahan bagi anak buahnya dengan melaksanakan program keselamatan pasien. Pimpinan mendorong dan menjamin implementasi program keselamatan pasien secara terintegrasi dalam organisasi melalui penerapan "Tujuh Langkah Menuju Keselamatan Pasien Rumah Sakit”.

Pemimpin harus membangun komitmen dan fokus yang kuat dan jelas guna mendukung staff untuk menjalankan program keselamatan pasien secara berkesinambungan, memprioritaskan atau mengintegrasikan program keselamatan pasien dalam setiap rapat dengan para pengambil keputusan, mengagendakan pelatihan tentang keselamatan pasien bagi semua staf secara berkala dan berkesinambungan. Pimpinan menjamin berlangsungnya program proaktif untuk identifikasi risiko keselamatan pasien dan program menekan atau mengurangi Kejadian Tidak Diharapkan. Pimpinan mendorong dan menumbuhkan komunikasi dan koordinasi antar unit dan individu berkaitan dengan pengambilan keputusan tentang keselamatan pasien. Pimpinan mengalokasikan sumber daya yang adekwat untuk mengukur, mengkaji, dan meningkatkan kinerja rumah sakit serta meningkatkan keselamatan pasien. Pimpinan mengukur dan mengkaji efektifitas kontribusinya dalam meningkatkan kinerja rumah sakit dan keselamatan pasien. Pada unit kerja berikan semangat kepada rekan kerja untuk secara aktif melaporkan setiap insiden yang terjadi dan insiden yang telah dicegah tetapi tetap terjadi juga, karena mengandung bahan pelajaran yang penting. Pemimpin harus mampu memotivasi bawahannya, salah satunya dengan pujian. Pujian yang diberikan oleh pemberi kerja pada saat pekerjaan yang 
selesai dilakukan sesuai dengan prosedur yang ditetapkan akan memberikan motivasi tersendiri untuk perawat.

\section{4) Pelaporan}

Indikator pelaporan dalam penerapan budaya keselamatan pasien berada dalam kategori cukup. Perawat diharuskan melaporkan kejadian kesalahan yang tidak disengaja dan kondisi yang mengakibatkan atau berpotensi mengakibatkan cedera yang dapat dicegah pada pasien, yang terdiri dari kejadian tidak diharapkan, kejadian nyaris cedera, kejadian tidak cedera dan kejadian potensial cedera. Melaporkan sebuah kejadian atau insiden keselamatan pasien masih jarang dilakukan atau pun bahkan jika ada pelaporan tentang insiden atau kejadian keselamatan pasien belum ada pelaporan secara resmi.

Hal ini disebabkan para perawat takut untuk melaporkan insiden yang terjadi pada pasien karena kesalahan yang dilakukannya. Perawat merasa takut akan hukuman dari penyelia atas kesalahan yang telah ia lakukan saat melakukan asuhan keperawatan. Sejatinya pelaporan insiden keselamatan pasien sangat dibutuhkan oleh semua pihak guna perbaikan pelayanan dalam hal ini khususnya asuhan keperawatan. Informasi dari pelaporan insiden keselamatan pasien yang akurat dan jelas dapat membantu identifikasi akar permasalahan bagaimana insiden tersebut bisa terjadi serta identifikasi faktor risiko sehingga insiden yang sama dapat dicegah untuk kemudian hari. Peran dan fungsi perawat yang salah satunya yaitu peran sebagai peneliti. Informasi yang benar dan jelas yang diperoleh dai sistem pelaporan, asesmen risiko, kajian insiden, dan audit serta analisis, digunakan untuk menentukan solusi.

\section{5) Respon Tidak Menghukum Terhadap Kesalahan}

Indikator respon tidak menghukum terhadap kesalahan ini menunjukkan bahwa dimasa

yang akan datang pelaporan terhadap insiden keselamatan pasien tidak semata-mata hanya berupa pelaporan insiden keselamatan, namun pelaporan tersebut hendaknya ditindaklanjuti guna memperbaiki kesalahan dan mencari akar permasalahan, tidak untuk menghukum perawat yang melakukan kesalahan atau berpengaruh terhadap penilainan kinerjanya. Ketika kesalahan dilaporkan, maka cukup melaporkan masalah sendiri dilaporkan menemukan jalan keluar tidak menunjukkan siapa pelaku harus dihukum. Belajar dari insiden keselamatan pasien hanya akan 
berhasil jika setiap permasalahan tidak dilihat sebagai kesalahan individu tetapi harus diperhatikan dengan pendekatan sistem dan pemahaman faktor manusia.

Sebagaimana diatur dalam Peraturan Menteri Kesehatan Republik Indonesia nomer 755/Menkes/Per/IV/2011 tentang pelaksanaan komite medis di rumah sakit bahwa audit medis dilakukan dengan memprioritaskan semua staf untuk menghilangkan blaming (menyalahkan), naming (menyebut atau mencari siapa yang salah), dan shaming (mempermalukan atau mengakui kesalahan). Untuk mampu belajar dari kesalahan harus ditekankan pada upaya mencari apa yang salah, mengapa kesalahan tersebut dapat terjadi, dan apa yang bisa dilakukan untuk memperbaiki kesalahan.

Keberhasilan penerapan keselamatan pasien ini menjadi tanggung jawab seluruh komponen dalam rumah sakit termasuk perawat. Perawat merupakan tenaga kesehatan yang selalu mendampingi pasien sehingga sangat berisiko melakukan kelalaian yang dapat menyebabkan pasien cedera bahkan mencapai angka 86\% (Maryam, 2009).

Disisi lain, perawat khususnya perawat pelaksana merupakan garda terdepan dalam menjamin keselamatan pasien terutama pada pasien rawat inap karena perawat pelaksana memiliki kuantitas kontak dengan pasien paling banyak dibandingkan tenaga kesehatan yang lain. Oleh karena itu, pengalaman perawat pelaksana dalam menjamin keselamatan pasien dapat menjadi sesuatu yang menarik untuk digali.

\section{PENUTUP}

Keselamatan pasien adalah prioritas utama dan harus segera dilaksanakan di rumah sakit karena dapat menyebabkan cedera langsung kepada pasien, terkait dengan kualitas dan nilai rumah sakit serta standar pelayanan yang harus dipenuhi oleh standar akreditasi rumah sakit terkait untuk versi 2012 yang mengacu pada Joint Commission International (JCI). Dalam penerapan program keselamatan pasien terdapat beberapa aspek yang mempengaruhi berjalannya program penerapan keselamatan pasien. Aspek-aspek tersebut antara lain: iklim organisasi, tingkat pengetahuan, komunikasi, dan etika. Budaya keselamatan pasien akan tercipta apabila tenaga kesehatan memiliki pemimpin Yang bersedia bekerja sama demi terlaksananya patient 
safety. Selain itu pengetahuan dan komunikasi juga berpengaruh terhadap terlaksananya patient safety.

\section{DAFTAR PUSTAKA}

Arifuddin, N.F. 2019. “ GAMBARAN BUDAYA KESELAMATAN PASIEN DI INSTALASI RAWAT INAP RUMAH SAKIT Dr. TAJUDDIN CHALID MAKASSAR TAHUN 2019 “. Skripsi. Fakultas Kedokteran Dan Ilmu Kesehatan. Universitas Islam Negeri Alauddin : Makassar

Harus, B. D., \& Sutriningsih , A. (2015). Pengetahuan Perawat Tentang Keselamatan Pasien dengan Pelaksanaan Prosedur Keselamatan Pasien Rumah Sakit. Jurnal CARE, Vol. 3, No 1, 26-32.

Herawati , Y. T. (2015). BUDAYA KESELAMATAN PASIEN DI RUANG RAWAT INAP RUMAH SAKIT X KABUPATEN JEMBER. Jurnal IKESMA . 11 (1), 52-60.

Isnaini, N. M., \& Roffi, M. (2014). PENGALAMAN PERAWAT PELAKSANA DALAM MENERAPKAN KESELAMATAN PASIEN. Jurnal Managemen Keperawatan Volume 2, No. 1, 30-37.

Mahdasari, M., \& dkk. (2016). PENINGKATAN KESELAMATAN DIRI PERAWAT MELALUI OPTIMALISASI FUNGSI MANAJEMEN . Jurnal Keperawatan Indonesia, Volume 19 No.3, 176-183.

PUJILESTARI, A. 2013. " GAMBARAN BUDAYA KESELAMATAN PASIEN OLEH PERAWAT DALAM MELAKSANAKAN PELAYANAN DI INSTALASI RAWAT INAP RSUP DR. WAHIDIN SUDIROHUSODO TAHUN 2013 “ · Skripsi. FAKULTAS KESEHATAN MASYARAKAT . UNIVERSITAS HASANUDDIN : MAKASSAR

Simamora, R. H. (2018). Buku ajar keselamatan pasien melalui timbang terima pasien berbasis komunikasi efektif: SBAR. Medan: USUpress.

Simamora, R. H. (2020). Learning of Patient Identification in Patient Safety Programs Through Clinical Preceptor Models. Medico Legal Update, 20(3), 553-556. 
Suryanto, D . T . F . 2018 . “ HUBUNGAN BUDAYA KESELAMATAN PASIEN DENGAN PELAPORAN INSIDEN KESELAMATAN PASIEN OLEH PERAWAT DI RUANG RAWAT INAP RUMAH SAKIt “. Skripsi.Fakultas Keperawatan. Universitas Sumatera Utara : Medan

Suci, W. P. (2018). PENINGKATAN BUDAYA KESELAMATAN PASIEN MELALUI PEMBERDAYAAN CHAMPION KESELAMATAN PASIEN . JKH Vol 2 No 2, 26-39.

Sujoso, A. D. (2012). DASAR-DASAR KESELAMATAN DAN KESEHATAN KERJA. Jember: UPT Penerbitan UNEJ.

Utarini, A. (2012). Keselamatan Pasien dan Mutu Pelayanan Kesehatan : Menuju Kemana? Jurnal Managemen Pelayanan Kesehatan Volume 15 No. 04, 159-160. 